\title{
MEDIA FILM SITUS ASTANA GEDE KAWALI \\ UNTUK MENINGKATKAN HASIL BELAJAR SEJARAH SISWA (PTK Di Kelas X IPA 1 SMA N 1 Baregbeg)
}

\author{
Aan Suryana ${ }^{1}$ \\ Dosen Pendidikan Sejarah Universitas Galuh Ciamis \\ Jl. R. E. Martadinata No. 150 Ciamis, 46274 Jawa Barat
}

\begin{abstract}
ABSTRAK
Penelitian Tindakan Kelas ini bertujuan untuk: mengetahui bagaimanakah implementasi media film situs Astana Gede Kawali dalam pembelajaran sejarah untuk meningkatkan kesadaran sejarah siswa kelas X IPA 1 SMA N 1 Baregbeg. Metode yang digunakan dalam penelitian ini adalah deskriptif kualitatif dari hasil penelitian tindakan kelas (PTK) berupa perlakuan (treatment) dengan menggunakan media film sejarah lokal situs Astana Gede Kawali dengan subjek penelitian adalah siswa kelas X IPA 1 SMA N 1 Baregbeg. Hasil penelitian menunjukan adanya peningkatan yang dicapai siswa adalah pada siklus I hasil pre test belajar siswa, yaitu memperoleh rata-rata 52,14, sedangkan untuk hasil post test siswa memperoleh rata-rata 74,76. Selanjutnya siklus II hasil pre test memperoleh rata-rata 60,23, kemudian hasil post test memperoleh rata-rata 79,52.
\end{abstract}

Kata Kunci: Media Film, Situs Astana Gede Kawali, dan Hasil Belajar

\section{ABSTRACT}

This Classroom Action Research aims to: find out how the implementation of the film media site Astana Gede Kawali in history learning to increase historical awareness of class X IPA 1 students of SMA $N 1$ Baregbeg. The method used in this study is descriptive qualitative from the results of classroom action research $(C A R)$ in the form of treatment using local historical film media, the Astana Gede Kawali site with research subjects as students of class X IPA 1 SMA N 1 Baregbeg. The results showed an increase achieved by students in the first cycle of the results of student pre-test, which obtained an average of 52.14, while for the post-test results students obtained an average of 74.76. Then the second cycle of the pre test results obtained an average of 60.23, then the post test results obtained an average of 79.52 .

\section{Keywords: Film Media, Astana Gede Kawali Site, and Learning Outcomes}

\section{PENDAHULUAN}

Pembelajaran sejarah menggunakan media film situs sejarah lokal sangat penting untuk diterapkan dilingkungan pendidikan, mulai jenjang SD, SMP, atau pun SMA. Hal ini, dikarenakan pembelajaran sejarah yang berbasis sejarah lokal memberikan manfaat bagi peningkatan kesadaran sejarah siswa. Seperti yang diungkapkan oleh Darmawan (Tt) bahwa penelitian tentang sejarah lokal akan memperdalam pengetahuan tentang dinamika sisiokultural dari bangsa Indonesia yang majemuk secara lebih dekat. Sering kali hal-hal yang ada di tingkat nasional baru dapat

\footnotetext{
${ }^{1}$ Penulis Koresponden

E-mail address: aansuryana64@gmail.com doi: http://dx.doi.org/10.25157/ja.v5i1.1914
}

dimengerti dengan baik apabila kita mengerti dengan baik pula perkembangan yang ada pada tingkat yang lebih kecil. Selanjutnya, masih menurut Darmawan (Tt) ada beberapa hal pentingnya mempelajari sejarah lokal anatar lain: 1. Untuk menilai kembali generalisasigeneralisasi yang sering terdapat dalam sejarah nasional (periodisasi,dualisme ekonomi,dll.) 2. Meningkatkan wawasan/pengetahuan kesejahteraan dari masing-masing kelompok yang akhirnya akan memperluas pandangan tentang "dunia" Indonesia. 3. Membantu sejarawan profesional membuat analisisanalisis kritis. 4. Menjadi sumber/ bahan/ data sejarah untuk kepentingan no.1 dan para peneliti lainnya.

Copyright@2018 Jurnal Artefak e-ISSN: 2580-0027 
Selain itu, menurut Abdullah (2005: 15) dalam (Kusnoto dan Minandar, 2017: 129) berpendapat bahwa sejarah lokal bersifat tunggal dan netral. Sejarah lokal tidak berbelit-belit, hanyalah tempat dan ruang. Jadi sejarah lokal hanyalah sejarah dari suatu tempat, yang batasan geografisnya dapat pada suatu tempat tinggal suatau bangsa, yang mencakup dua-tiga daerah administratif, dan juga dapat pula suatu kota atau desa. Dengan demikian, sederhananya sejarah lokal dirumuskan sebagai kisah kelampauan dari kalangan kelompok-kelompok masyarakat yang berada pada daerah geografis yang terbatas. Dalam bagian lain, Abdullah (1992: 239) dalam Supardi (2006: 124) menegaskan bahwa penulisan sejarah lokal begitu besar artinya dalam upaya pembahasan yang lebih detail tentang fenomena dan peristiwa nasional yang bersifat berkeping. Sejarah lokal diharapkan mampu memberikan sumbangan berupa kesadaran sebagai bangsa yang multi budaya, ditunjukkan dengan pengakuan akan kelemahan masing-masing dengan membangun kesederajatan di antara kebinekaan. Dalam multikulturalisme diharapkan berlangsung iklim demokratis yang mampu mengakomodasi berbagai kepentingan dan perbedaan. Kemudian, hasil penelitian yang dilakukan oleh Kusmayadi dan Suryana (2019) dengan judul "Pengaruh Model Pembelajaran Kooperatif STAD Berbantuan Media Film Situs Astana Gede Kawali Terhadap Kesadaran Sejarah" yang dilakukan di SMA N 1 Baregbeg menunjukan adanya perbedaan pengaruh antara model dan media pembelajaran terhadap kesadaran sejarah. Selain itu, hasil penelitian pun menunjukan terdapat pengaruh kesadaran sejarah terhadap hasil belajar siswa.

Namun, realitasnya urgennya pembelajaran sejarah lokal bagi generasi muda masih belum dipahami secara mendalam. Masih banyak generasi muda saat ini tidak mengetahui sejarah dari daerahnya sendiri. Hal ini berdasarkan hasil penelitian yang dilakukan oleh peneliti di SMA N 1 Baregbeg, yaitu melalui pemberian tes sebanyak 20 butir soal. Dari hasil tes yang telah dilakukan hanya $20 \%$ siswa yang lulus memenuhi KKM. Kondisi ini menunjukan bahwa sebagian siswa belum mengetahui dan memahami tentang sejarah lokal yang ada di daerahnya, khususnya sejarah lokal di kabupaten Ciamis.

Melihat kondisi di atas, maka perlu dilakukan pembaharuan dalam penggunaan media atau model pembelajaran. Penelitian ini menerapkan media film situs Astana Gede Kawali sebagai media pembelajaran untuk meningkatkan hasil belajar sejarah siswa. Pada kegiatan penelitian ini peneliti mengintegrasikan media film sejarah lokal yang ada di kabupaten Ciamis, yaitu situs Astana Gede Kawali ke dalam kegiatan pembelajaran di kelas, sehingga siswa menyaksikan langsung peninggalan kerajaan Galuh di situs Astana Gede Kawali berupa prasasti yang terdiri dari 6 bauh prasasti. Berdasarkan penjelasan di atas, maka dilakukan penelitian dengan judul "Media Film Situs Astana Gede Kawali Untuk Meningkatkan Hasil Belajar Sejarah Siswa (PTK Di Kelas X IPA 1 SMA N 1 Baregbeg)".

Untuk itu rumusan masalah dalam penelitian ini adalah bagaimanakan pelaksanaan pembelajaran sejarah menggunakan media film situs Astana Gede Kawali untuk meningkatkan hasil belajar sejarah siswa kelas X IPA 1 SMA N 1 Baregbeg. Sedangkan tujuan penelitian ini yakni untuk mengetahui bagaimanakah pelaksanaan pembelajaran sejarah menggunakan media film situs Astana Gede Kawali untuk meningkatkan hasil belajar sejarah siswa kelas $\mathrm{X}$ IPA 1 SMA N 1 Baregbeg.

\section{METODE PENELITIAN}

Dalam kegiatan penelitian ini metode yang digunakan adalah deskriptif kualitatif dari hasil penelitian tindakan kelas (PTK) berupa perlakuan (treatment) dengan menggunakan media film sejarah lokal situs Astana Gede Kawali di kelas X IPA 1 SMA N 1 Baregbeg. Menurut Hopkins (dalam Wiriaatmadya, 2007: 11) (dalam Rahdiyanta, 2012) PTK adalah penelitian yang mengkombinasikan prosedur penelitian dengan tindakan substantif, suatu tindakan yang dilakukan dalam disiplin inkuiri atau suatu usaha seseorang untuk memahami apa yang sedang terjadi, sambil terlihat dalam sebuah proses perbaikan dan perubahan. Selanjutnya, Kemmis Dan Taggart (1988) (dalam Rahdiyanta, 2012) menyatakan bahwa PTK sebagai bentuk refleksi diri kolektif yang didahulukan oleh para partisipan dalam situasi sosial dengan tujuan untuk meningkatkan produktivitas, rasionalitas, keadilan pada persoalan sosial, atau praktik pendidikan. Data penelitian diperoleh dari pengamatan kegiatan pembelajaran, informan (siswa, guru, dan kepala sekolah), dokumen, dan foto kegiatan. Melalui 


\section{Aan Suryana}

Media Film Situs Astana Gede Kawali Untuk Meningkatkan Hasil Belajar Sejarah Siswa (PTK Di Kelas X IPA 1 SMA N 1 Baregbeg)

tahapan palnning (perencanaan), action (pelaksanaan), observing, dan reflecting.

\section{HASIL PENELITIAN DAN PEMBAHASAN}

\section{Perencanaan Pembelajaran Sejarah Menggunakan Media Film Situs Astana Gede Kawali}

Berdasarkan hasil penilitian siklus I, dan II, terdapat relevansi dengan teori-teori yang dijadikan acuan dalam penelitian ini. Fokus penelitian adalah implementasi pembelajaran sejarah menggunakan media film situs Astana Gede Kawali untuk meningkatkan kesadaran sejarah siswa kelas X IPA 1 SMA N 1 Baregbeg. Penelitian yang dilaksanakan di SMA N 1 Baregbeg dengan mengimplementasikan media film situs Astana Gede Kawali dalam pebelajaran sejarah mengalami keberhasilan yang dilihat dari hasil penelitian yang telah dilakukan. Meskipun dalam pelaksanaannya mengalami beberapa kendala, yaitu penggunaan waktu yang masih kurang efektif, sehingga demi terlaksananya kegiatan pembelajaran yang bermutu, maka dilakukan beberapa perencanaan.

Pada pelaksanaan kegiatan penelitian, terlebih dahulu peneliti melakukan observasi awal ke sekolah yang menjadi target penelitian, yaitu kelas X IPA 1 SMA N 1 Baregbeg. Hal ini dilakukan untuk mengetahui tentang pengetahuan awal siswa mengenai sejarah lokal yang ada di kabupaten Ciamis. Selain itu, observasi awal ini dilakukan untuk menyamakan materi dengan media pembelajaran yang akan digunakan, yaitu media film situs Astana Gede Kawali, sedangkan untuk materi dalam peneltian ini adalah "Kerajaan Hindu-Budha di Indonesia". Kemudian, untuk mengetahui pengetahuan awal siswa, maka diberikan soal pilihan ganda sebanyak 20 butir soal. Sebelum kegiatan pembelajaran siklus I dilaksanakan peneliti menemukan beberapa temuan, yaitu:

1. Guru menyusun RPP terlebih dahulu berdasarkan silabus yang telah disediakan.

2. Pada saat pembelajaran guru hanya menggunakan metode ceramah dan diskusi, belum menerapkan media pembelajaran film situs Astana Gede Kawali.

3. Siswa hanya diberikan tugas yang sama ketika pembelajaran selsai.

Setelah menemukan beberapa temuan dalam proses pembelajaran sejarah, maka perencanaan model pembelajaran menggunakan media film situs Astana Gede Kawali untuk meningkatkan hasil belajar siswa pada siklus I adalah sebagai berikut:

1. Menetapkan pelaksanaan penelitian mulai bulan Juli-Agustus 2018.

2. Menentukan kelas yang akan menjadi objek penelitian, yaitu kelas X IPA 1 SMA N 1 Baregbeg.

3. Peneliti melakukan diskusi terlebih dahulu dengan guru mengenai situasi dan kondisi siswa yang ada di kelas X IPA 1.

4. Menyusun RPP dengan guru mitra, yaitu tentang "Kerajaan Hindu-Budha di Indnesia.

5. Menetapkan media pembelajaran yaitu media film situs Astana Gede Kawali.

6. Membuat tujuan pembelajaran, yaitu:

a. Siswa mampu menjelaskan contoh kerajaan Hindu-Budha di Indonesia

b. Siswa mampu menjelaskan salah satu kerajaan Hindu di kabupaten Ciamis

c. Siswa mampu memahami nilai-nilai filosofi yang terdapat dalam prasasti Astana Gede Kawali.

7. Menyusun format penilaian.

Berdasarkan hasil penelitian pada siklus I, diperoleh hasil bahwa pada siklus ini kegiatan pembelajaran belum sesuai dengan tujuan yang telah ditetapkan, sehingga diperlukan perbaikan. Untuk itu, maka dilakukan penelitian tahap selanjutnya, yaitu penelitian siklus II dengan menggunakan media pembelajaran yang sama dan materi yang sama.

\section{Pelaksanaan Pembelajaran Sejarah Menggunakan Media Film Situs Astana Gede Kawali Untuk Meningkatkan Hasil Belajar Sejarah \\ a. Tindakan Siklus I}

Pelaksanaan penelitian tindakan pada siklus I dijelaskan hasil penelitian yang terdiri dari; a) perencanaan, b) pelaksanaan, c) observasi, dan d) refleksi.

\section{1) Perencanaan} yaitu:

Kegiatan perencanaan pada siklus I,

a) Menentukan kelas sebagai objek penelitian, yaitu kelas X IPA I SMA N I Baregbeg.

b) Melakukan penelitian mengenai pelaksanaan kegiatan pembelajaran yang biasa dilakukan.

c) Mendiskusikan dan menentukan materi yang akan digunakan pada kegiatan penelitian berdasarkan silabus dan RPP dengan Kompetensi Dasar: Kerajaan Hindu Budha di Indonesia. 
d) Mempersiapkan

perangkat pembelajaran seperti media film situs Astana Gede Kawali, lembar penilaian, dan menyiapkan tugas untuk pelaksanaan evaluasi.

e) Menetukan alokasi waktu, yaitu hari Kamis jam ke 3 dan 4 (1X45 menit).

f) Pembelajaran dengan menggunakan media film situs Astana Gede Kawali dan metode ceramah serta diskusi sebagai pendukung kegiatan pembelajaran sejarah di kelas.

\section{2) Pelaksanaan}

Pelaksanaan kegiatan pembelajaran pembelajaran pada siklus I, dilaksanakan sebanyak satu kali pertemuan, yaitu tanggal 2 Agustus 2018 di kelas X IPA I SMA N I Baregbeg yang berjumlah 21 orang. Di sini peneliti sebagai pengamat dan guru mitra sebagai objek yang diamati dengan menggunakan media film situs Astana Gede Kawali. Yang menjadi model adalah Bapak Dadan, S.Pd dalam materi "Kerajaan HinduBudha di Indonesia. Adapun proses belajar mengajar mengacu pada RPP yang telah disiapkan oleh guru dan peneliti.

Pertemuan I yang dilaksanakan pada tanggal 2 Agustus 2018 yang merujuk pada langkah-langkah pembelajaran dengan menerapkan media film situs Astana Gede Kawali sebagai berikut: a) penyampaian tujuan dan motivasi, b) pembagian kelompok, c) penjelasan dari guru tentang materi yang akan diajarkan, d) pelaksanaan kegiatan diskusi dengan melakukan analisis dari media film yang sudah ditayangkan.

Pendahuluan, guru melakukan kegiatan apersepsi selama 5 menit, yaitu memeriksa daftar hadir siswa serta memeriksa persiapan siswa mengikuti kegiatan pembelajaran. Kemudian, guru menyampaikan tujuan dan memberikan motivasi kepada siswa supaya mengikuti pembelajaran sejarah dengan baik. Guru juga menjelaskan media yang digunakan dalam pembelajaran, yaitu media film situs Astana Gede Kawali yang bertujuan supaya siswa lebih mengenal dan memahami tentang sejarah lokal yang ada di daerahnya. sebelum kegiatan pembelajaran dilakukan kegiatan pretest selama 10 menit dengan tujuan untuk mengetahui kemampuan awal siswa dalam mengikuti pembelajaran sejarah.

Kegiatan inti dilaksanakan selama 30 menit, yaitu pada tahap eksplorasi guru membagi siswa menjadi 5 kelompok yang masing-masing kelompok terdiri dari 4-5 orang. Selanjutnya, guru menyampaikan penjelasan materi secara garis besar, kemudian dilanjutkan siswa bersama kelompoknya.

Tahap elaborasi selama 10 menit, yaitu guru memberikan kesempatan kepada siswa untuk belajar secara tim sesuai dengan kelompok yang telah dibentuk. Kegiatan siswa dalam diskusi adalah menganalisis materi tentang sejarah lokal yang ada di kabupaten Ciamis yaitu peninggalan kerajaan Galuh berupa situs yang ada di Kawali, yaitu sistus Astana Gede Kawali yang di dalamnya terdapat 6 buah prasasti yang memiliki nilai filosofis bagi perkembangan kabupaten Ciamis. Selanjutnya, hasil diskusi dikumpulkan untuk diperiksa oleh guru.

Tahap konfirmasi selama 5 menit, yaitu guru sebagai fasilitator meluruskan jawaban dari pertanyaan yang disampaikan kelompok satu ke kelompok lainnya.

Penutup, kegiatan penutup pada pembelajaran dilakukan selama 15 menit, guru dan siswa membuat kesimpulan dari materi yang sudah dijelaskan dan selanjutnya guru memberikan penilaian dari kegiatan kelompok yang telah dilakukan siswa. Namun, sebelum kegiatan pembelajaran berakhir siswa diberikan postest sebanyak 20 soal pilihan ganda untuk mengukur seberapa jauh pemahaman siswa terhadap pembelajaran sejarah. dari hasil perhitungan hasil prestasi siswa pada siklus I hasil pre test belajar siswa, yaitu memperoleh rata-rata $\mathbf{5 2 , 1 4}$, sedangkan untuk hasil post test siswa memperoleh rata-rata 74,76 .

\section{3) Pengamatan}

Tahap pengamatan pada siklus I menjelaskan mengenai hasil tindakan yang didapat dari hasil pengamatan proses belajar mengajar yang dilakukan selama satu kali pertemuan oleh guru mata pelajaran, yaitu meliputi; kekompakan siswa dalam melaksanakan diskusi, keaktifan siswa dalam mengikuti kegiatan pembelajaran, tingkat pemahaman siswa terhadap materi sejarah lokal situs Astana Gede Kawali, serta minat siswa mengikuti pembelajaran sejarah. pada kegiatan ini, peneliti bersama guru mitra melakukan pengamatan terhadap proses belajar mengajar di kelas dengan mengisi lembar observasi untuk kegiatan pembelajaran. Pertemuan pada siklus I 
kegiatan pembelajaran sudah diarahkan pada penggunaan media film Situs Astana Gede Kawali.

Proses belajar mengajar dilakukan selama 30 menit. Guru sesekali mengarahkan siswa supaya mengikuti pembelajaran dengan baik, namun tetap masih ada beberapa siswa yang melakukan kegaiatan di luar dari kegiatan yang seharusnya dilakukan, seperti mengobrol atau asyik sendiri. Tetapi dengan kesabaran yang dimiliki guru akhirnya siswa yang melakukan kegiatan yang tidak sesuai dengan diarahkan dapat diatasi. Pada pertemuan ini sudah dibentuk kelompok yang terdiri dari 5 kelompok. Setiap kelompok diberikan tugas untuk menganalisis film yang diberikan guru, yaitu film Situs Astana Gede Kawali. Pada pertemuan ini sebagian siswa sudah ada yang memahami tentang situs Astana Gede Kawali. Selanjutnya dilakukan posttest siklus I untuk melihat hasil belajar sejarah siswa. Dari hasil pengamatan dapat dilihat hasil rekapitulasi pre dan post test siklus I. Distribusi frekuensi tes prestasi dapat dilihat pada tabel di bawah ini:

\section{Tabel 1}

Distribusi Frekuensi Tes Hasil Belajar (Pretest)

\begin{tabular}{|l|l|l|}
\hline Frekuensi & Interval & Prosentase (\%) \\
\hline $20-29$ & 1 & 4,76 \\
\hline $30-39$ & 5 & 23,8 \\
\hline $40-49$ & 3 & 14,28 \\
\hline $50-59$ & 3 & 14,28 \\
\hline $60-69$ & 5 & 23,8 \\
\hline $70-79$ & 3 & 14,28 \\
\hline $80-89$ & 1 & 4,76 \\
\hline Jumlah & 21 & 100 \\
\hline
\end{tabular}

Tabel 2

Distribusi Frekuensi Tes Hasil Belajar (Postest)

\begin{tabular}{|l|l|l|}
\hline Frekuensi & Interval & Prosentase (\%) \\
\hline $50-59$ & 1 & 4,76 \\
\hline $60-69$ & 3 & 14,28 \\
\hline $70-79$ & 9 & 42,85 \\
\hline $80-89$ & 7 & 33,33 \\
\hline $90-99$ & 1 & 4,76 \\
\hline Jumlah & 21 & 100 \\
\hline
\end{tabular}

\section{4) Refleksi}

hasil refleksi pada siklus I sudah lebih baik dibandingkan dengan pra siklus. Hal ini, dapat dilihat dari hasil catatan lapangan, dimana penulis melakukan wawancara dengan guru mitra pada siklus I, penulis menanyakan tentang bagaimana hasil belajar sejarah siswa selama ini? Guru mitra menjelaskan bahwa hasil belajar sejarah siswa selama ini masih banyak yang belum memenuhi KKM. Berdasarkan hasil pengamatan dari siklus I, peneliti dan guru mitra berdiskusi supaya pertemuan selanjutnya lebih baik. Dari pelaksanaan kegiatan pemebelajaran diperoleh beberapa temuan, diantaranya:

a) Pada pertemusn siklus I guru belum menyampaikan Kompetensi Dasar secara jelas, sehingga banyak siswa yang kurang paham.

b) Guru masih mendominasi dalam memberikan penejlasan kepada siswa, sehingga siswa masih bersikap pasif.

c) Dalam kegiatan diskusi masih didominasi oleh siswa yang memiliki nilai akadmis lebih tinggi.

d) Pada kegiatan diskusi kelompok keterlibatan kelompok-kelompok masih kurang.

e) Belum semua langkah dalam pembelajaran dapat dilaksanakan secara efektif.

f) Pada saat pelaksanaan post test masih banyak siswa yang kurang percaya diri, sehingga hasil yang diperoleh belum sesuai dengan yang diharapkan.

\section{b. Tindakan Siklus II}

Pelaksanaan penelitian tindakan pada siklus II masih sama dengan apa yang dilakukan di siklus I, yaitu terdiri dari; a) perencanaan, b) pelaksanaan, c) observasi, dan d) refleksi. Kegiatan siklus II dilaksanakan pada tanggal 9 Agustus 2018 dan masih mengunakan media film situs Astana Gede Kawali.

\section{1) Perencanaan}

Berdasarkan hasil temuan dari siklus I, yaitu guru dan siswa masih belum bisa melaksanakan langkah-langkah pembelajaran dengan menggunakan media film situs Astana Gede Kawali secara efektif, maka peneliti dan guru mitra melakukan diskusi balikan untuk memperbaiki kegiatan siklus I. Pada kegiatan diskusi ini dijelaskan bahwa kehadiran peneliti bukan sebagai pengawas yang akan mencari kesalahan, tetapi untuk dijadikan mitra dalam kegiatan oenelitian tindakan kelas. yaitu:

Kegiatan perencanaan pada siklus II,

a) Guru sudah melaksanakan kegiatan pembelajaran sesuai dengan langkahlangkah dalam pembelajaran dengan 
menggunakan media film situs Astana Gede Kawali.

b) Guru sudah bisa menyampaikan materi secara efektif dibandingkan dengan siklus I.

c) Guru bertindak sebagai fasilitator dan motivator dalam pembelajaran, sehingga memberikan banyak kesempatan kepada siswa untuk lebih aktif dalam kegiatan pembelajaran.

d) Guru sudah bisa melakukan kegiatan penutup secara lebih efektif.

\section{2) Pelaksanaan}

Kegiatan pembelajaran pada siklus II, dilaksanakan sebanyak satu kali pertemuan, yaitu tanggal 9 Agustus 2018 di kelas X IPA I SMA N I Baregbeg yang berjumlah 21 orang, dengan materi yang sama yaitu, "Kerajaan Hindu-Budha di Indonesia. Pertemuan pada siklus II yang dilaksanakan pada tanggal 9 Agustus 2018 yang merujuk pada langkah-langkah pembelajaran dengan menerapkan media film situs Astana Gede Kawali sebagai berikut: a) penyampaian tujuan dan motivasi, b) pembagian kelompok, c) penjelasan dari guru tentang materi yang akan diajarkan, d) pelaksanaan kegiatan diskusi dengan melakukan analisis dari media film yang sudah ditayangkan.

Pendahuluan, guru melakukan kegiatan apersepsi selama 5 menit, yaitu memeriksa daftar hadir siswa serta memeriksa persiapan siswa mengikuti kegiatan pembelajaran. Kemudian, guru menyampaikan tujuan dan memberikan motivasi kepada siswa supaya mengikuti pembelajaran sejarah dengan baik. Guru juga menjelaskan media yang digunakan dalam pembelajaran, yaitu masih sama menggunakan media film situs Astana Gede Kawali yang bertujuan supaya siswa lebih mengenal dan memahami tentang sejarah lokal yang ada di daerahnya. Selanjutnya, guru membahas kembali materi yang disampaikan pada pertemuan sebelumnya. Kemudian, dilakukan kegiatan pretest selama 10 menit dengan tujuan untuk mengetahui kemampuan awal siswa dalam mengikuti pembelajaran sejarah.

Kegiatan inti dilaksanakan selama 30 menit, yaitu pada tahap eksplorasi guru menyampaikan penjelasan materi secara garis besar, kemudian dilanjutkan siswa bersama kelompoknya. Pada tahap ini materi yang disampaikan adalah tentang peninggalan kerajaan Galuh yang ada di situs Astana Gede Kawali.

Tahap elaborasi selama 10 menit, yaitu guru menayangkan film situs Astana Gede Kawali yang di dalamnya menjelaskan tentang benda-benda peninggalan dari kerajaan Galuh yang terdapat di situs ini, slah satunya berupa prasasti yang terdiri dari 6 buah mulai dari prasasti kawali I-IV. Dalam hal ini, guru memberikan kesempatan kepada siswa untuk menganalisis film yang telah ditayangkan secara kelompok, sehingga diharapkan setelah penayangan film tersebut hasil belajar siswa meningkat.

Tahap konfirmasi selama 5 menit, yaitu guru sebagai fasilitator memberikan balikan secara positif terhadap apa yang dilakukan oleh siswa. Kemudian, meluruskan jawaban dari pertanyaan yang disampaikan kelompok satu ke kelompok lainnya. Penutup, kegiatan penutup pada pembelajaran dilakukan selama 15 menit, guru dan siswa membuat kesimpulan dari materi yang sudah dijelaskan dan selanjutnya guru memberikan penilaian dari kegiatan kelompok yang telah dilakukan siswa. Namun, sebelum kegiatan pembelajaran berakhir siswa diberikan postest sebanyak 20 soal pilihan ganda untuk mengukur seberapa jauh pemahaman siswa terhadap pembelajaran sejarah. Berdasarkan hasil perhitungan prestasi siswa pada siklus II hasil pre test memperoleh rata-rata 60,23, kemudian hasil post test memperoleh ratarata 79,52 .

\section{3) Pengamatan}

Tahap pengamatan pada siklus II menjelaskan mengenai hasil tindakan yang didapat dari hasil pengamatan proses belajar mengajar yang dilakukan selama satu kali pertemuan oleh guru mata pelajaran, yaitu meliputi; kekompakan siswa dalam melaksanakan diskusi, keaktifan siswa dalam mengikuti kegiatan pembelajaran, tingkat pemahaman siswa terhadap materi sejarah lokal situs Astana Gede Kawali, serta hasil belajar sejarah siswa. Pada kegiatan ini, peneliti bersama guru mitra melakukan pengamatan terhadap proses belajar mengajar di kelas dengan mengisi lembar observasi untuk kegiatan pembelajaran. Pertemuan pada siklus II kegiatan pembelajaran tetap diarahkan pada penggunaan media film Situs Astana Gede Kawali. 
Proses belajar mengajar dilakukan selama 30 menit. Guru sudah bisa memberikan kesempatan yang banyak bagi siswa untuk lebih aktif dalam mengikuti kegiatan pembelajaran. Kemudian, langkahlangkah pembelajaran sejarah dengan menggunakan media film situs Astana Gede Kawali sudah bisa dilakukan secara efektif dan hasil belajar sejarah siswa pun sudah mengalami peningkatan dibandingkan dengan siklus I. Dari hasil pengamatan dapat dilihat hasil rekapitulasi pre dan post test siklus II. Distribusi frekuensi tes prestasi dapat dilihat pada tabel di bawah ini:

Tabel 3

Distribusi Frekuensi Tes Hasil Belajar (Pretest)

\begin{tabular}{|l|l|l|}
\hline \multicolumn{1}{|c|}{ Frekuensi } & Interval & \multicolumn{1}{|c|}{$\begin{array}{c}\text { Prosentase } \\
(\boldsymbol{\%})\end{array}$} \\
\hline $30-39$ & 2 & 9,52 \\
\hline $40-49$ & 3 & 14,28 \\
\hline $50-59$ & 4 & 19,04 \\
\hline $60-69$ & 4 & 19,04 \\
\hline $70-79$ & 5 & 23,80 \\
\hline $80-89$ & 3 & 14,28 \\
\hline Jumlah & 21 & 100 \\
\hline
\end{tabular}

Tabel 4

Distribusi Frekuensi Tes Hasil Belajar (Postest)

\begin{tabular}{|l|l|l|}
\hline \multicolumn{1}{|c|}{ Frekuensi } & Interval & \multicolumn{1}{|c|}{$\begin{array}{c}\text { Prosentase } \\
(\%)\end{array}$} \\
\hline $60-69$ & 1 & 4,76 \\
\hline $70-79$ & 7 & 33,33 \\
\hline $80-89$ & 11 & 52,38 \\
\hline $90-99$ & 2 & 9,52 \\
\hline Jumlah & 21 & 100 \\
\hline
\end{tabular}

\section{4) Refleksi}

Hasil refleksi pada siklus II sudah lebih baik dibandingkan dengan siklus II. Hal ini, dapat dilihat dari hasil catatan lapangan, dimana penulis melakukan wawancara dengan guru mitra dan juga siswa, penulis menanyakan tentang bagaimana tentang penggunaan media fil situs Astana Gede Kawali? Guru mitra dan siswa menjelaskan bahwa penggunaan media film situs Astana Gede Kawali sangat efektif dan menarik untuk meningkatkan pemahaman siswa tentang sejarah lokal yang ada di daerahnya, sehingga mampu meningkatkan hasil belajar sejarah siswa. Berdasarkan hasil pengamatan dari siklus II, peneliti dan guru mitra berdiskusi, karena hasil pada siklus II sudah sesuai dengan yang diharapkan, maka kegiatan penelitian dihentikan. Dari pelaksanaan kegiatan pemebelajaran diperoleh beberapa temuan, diantaranya:

a) Guru sudah menyampaikan tujuan pembelajaran dengan baik dan mampu dipahami oleh siswa.

b) Guru sudah memberikan kesempatan yang lebih banyak kepada siswa untuk mengeksplor pengetahuan mereka.

c) Kegiatan diskusi sudah bisa dilakukan secara efektif.

d) Langkah-langkah dalam pembelajaran sudah bisa dilaksanakan dengan baik.

e) Hasil belajar sejarah siswa sudah sesuai dengan KKM.

Hasil Penggunaan Media Film Situs Astana Gede Kawali Untuk Meningkatkan Hasil Belajar Siswa dan Kesadaran Sejarah

Tabel 5

\begin{tabular}{|l|l|l|l|}
\hline $\begin{array}{l}\text { Nama } \\
\text { Siswa }\end{array}$ & \multicolumn{1}{|c|}{ Skor } & $\begin{array}{l}\text { Nama } \\
\text { Siswa }\end{array}$ & \multicolumn{2}{|c|}{ Skor } \\
\hline \multicolumn{2}{|c|}{ Pretest } & \multicolumn{2}{|c|}{ Postest } \\
\hline 1. & 30.0 & 1. & 70 \\
\hline 2. & 40.0 & 2. & 85 \\
\hline 3. & 65.0 & 3. & 75 \\
\hline 4. & 25.0 & 4. & 50 \\
\hline 5. & 75.0 & 5. & 85 \\
\hline 6. & 35.0 & 6. & 70 \\
\hline 7. & 75.0 & 7. & 80 \\
\hline 8. & 55.0 & 8. & 70 \\
\hline 9. & 60.0 & 9. & 75 \\
\hline 10. & 60.0 & 10. & 80 \\
\hline 11. & 30.0 & 11. & 75 \\
\hline 12. & 75.0 & 12. & 80 \\
\hline 13. & 45.0 & 13. & 65 \\
\hline 14. & 50.0 & 14. & 75 \\
\hline 15. & 45.0 & 15. & 75 \\
\hline 16. & 35.0 & 16. & 80 \\
\hline 17. & 80.0 & 17. & 90 \\
\hline 18. & 60.0 & 18. & 85 \\
\hline 19. & 35.0 & 19. & 75 \\
\hline 20. & 55.0 & 20. & 65 \\
\hline 21. & 65.0 & 21. & 65 \\
\hline $\begin{array}{l}\text { Rata- } \\
\text { rata }\end{array}$ & $\mathbf{1 0 9 5 / 2 1 = 5 2 , 1 4}$ & $\begin{array}{l}\text { Rata- } \\
\text { rata }\end{array}$ & $\mathbf{1 5 7 0 / 2 1 = 7 4 , 7 6}$ \\
\hline & & & \\
\hline
\end{tabular}

Berdasarkan tabel di atas menunjukan hasil pretest siswa yang mencapai KKM hanya $19,04 \%$, sedangkan sisanya belum sesuai dengan tujuan yang telah ditetapkan. Kemudian tabel di atas menunjukan nilai terendah siswa adalah 25 dan nilai tertinggi 80 . Sedangkan untuk hasil postest, siswa yang mendapatkan nilai sesuai KKM meningkat menjadi $66,66 \%$, dengan nilai 
terendah yaitu 50 dan nilai tertinggi 90 . Hal ini menunjukan pengunaan media film situs Astana Gede Kawali efektif dalam meningkatkan hasil belajar siswa. Namun meskipun demikian, hasil yang dicapai siswa pada siklus I belum sesuai dengan KKM yang ditentukan, yaitu siswa minimal mendapat nilai rata-rata secara keseluruhan $\geq 75$. Untuk mendapatkan hasil yang sesuai dengan tujuan yang telah ditetapkan, maka dilakukan penelitian siklus II.

Tabel 6

Distribusi Frekuensi Tes Hasil Belajar (Pretest)

\begin{tabular}{|l|l|l|}
\hline Frekuensi & Interval & Prosentase (\%) \\
\hline $20-29$ & 1 & 4,76 \\
\hline $30-39$ & 5 & 23,8 \\
\hline $40-49$ & 3 & 14,28 \\
\hline $50-59$ & 3 & 14,28 \\
\hline $60-69$ & 5 & 23,8 \\
\hline $70-79$ & 3 & 14,28 \\
\hline $80-89$ & 1 & 4,76 \\
\hline Jumlah & 21 & 100 \\
\hline
\end{tabular}

Tabel 7

Distribusi Frekuensi Tes Hasil Belajar (Postest)

\begin{tabular}{|l|l|l|}
\hline Frekuensi & Interval & Prosentase (\%) \\
\hline $50-59$ & 1 & 4,76 \\
\hline $60-69$ & 3 & 14,28 \\
\hline $70-79$ & 9 & 42,85 \\
\hline $80-89$ & 7 & 33,33 \\
\hline $90-99$ & 1 & 4,76 \\
\hline Jumlah & 21 & 100 \\
\hline
\end{tabular}

\section{Hasil Penelitian Siklus II}

Seperti halnya penelitian pada siklus I, hasil penelitian siklus II juga diperoleh dari pemberian tes kepada siswa, yaitu melalui pretest dan posttest. Tujuannya untuk mengetahui sejauh mana kemampuan siswa dalam penguasaan materi jika dibandingkan dengan siklus I. Adapun data yang diperoleh dari penelitian siklus II dapat dilihat pada tabel di bawah ini:

Tabel 8

Data Hasil Pretest dan Postest Siklus II

\begin{tabular}{|c|c|c|c|}
\hline $\begin{array}{c}\text { Nama } \\
\text { Siswa }\end{array}$ & Skor & $\begin{array}{c}\text { Nama } \\
\text { Siswa }\end{array}$ & Skor \\
\hline \multicolumn{2}{|c|}{ Pretest } & \multicolumn{2}{|c|}{ Postest } \\
\hline 1. & 50.0 & 1. & 75 \\
\hline 2. & 55.0 & 2. & 90 \\
\hline 3. & 60.0 & 3. & 80 \\
\hline 4. & 30.0 & 4. & 65 \\
\hline 5. & 80.0 & 5. & 85 \\
\hline 6. & 50.0 & 6. & 75 \\
\hline
\end{tabular}

\begin{tabular}{|c|c|c|c|}
\hline 7. & 80.0 & 7. & 80 \\
\hline 8. & 65.0 & 8. & 80 \\
\hline 9. & 75.0 & 9. & 85 \\
\hline 10. & 70.0 & 10. & 80 \\
\hline 11. & 55.0 & 11. & 75 \\
\hline 12. & 75.0 & 12. & 80 \\
\hline 13. & 45.0 & 13. & 80 \\
\hline 14. & 75.0 & 14. & 75 \\
\hline 15. & 45.0 & 15. & 75 \\
\hline 16. & 35.0 & 16. & 80 \\
\hline 17. & 85.0 & 17. & 90 \\
\hline 18. & 75.0 & 18. & 85 \\
\hline 19. & 40.0 & 19. & 85 \\
\hline 20. & 60.0 & 20. & 75 \\
\hline 21. & 60.0 & 21. & 75 \\
\hline
\end{tabular}

Rata-rata $1265 / 21=60,23$ Rata-rata $1670 / 21=79,52$

Berdasarkan tabel di atas menunjukan hasil pretest siswa yang mencapai KKM mengalami peningkatan dari siklus I, yaitu $33,33 \%$, sedangkan sisanya belum sesuai dengan tujuan yang telah ditetapkan. Kemudian tabel di atas menunjukan nilai terendah siswa adalah 35 dan nilai tertinggi 85 . Sedangkan untuk hasil postest, siswa yang mendapatkan nilai sesuai KKM meningkat menjadi 95,23\%, dengan nilai terendah yaitu 65 dan nilai tertinggi 90. Hal ini menunjukan penggunaan media film situs Astana Gede Kawali efektif dalam meningkatkan hasil belajar siswa. Berdasarkan kondisi di atas, maka penelitian ini dihentikan.

Tabel 9

Distribusi Frekuensi Tes Hasil Belajar (Pretest)

\begin{tabular}{|c|c|c|}
\hline Frekuensi & Interval & $\begin{array}{c}\text { Prosentase } \\
(\mathbf{\%})\end{array}$ \\
\hline $30-39$ & 2 & 9,52 \\
\hline $40-49$ & 3 & 14,28 \\
\hline $50-59$ & 4 & 19,04 \\
\hline $60-69$ & 4 & 19,04 \\
\hline $70-79$ & 5 & 23,80 \\
\hline $80-89$ & 3 & 14,28 \\
\hline Jumlah & 21 & 100 \\
\hline
\end{tabular}

Tabel 10

Distribusi Frekuensi Tes Hasil Belajar (Postest)

\begin{tabular}{|c|c|c|}
\hline Frekuensi & Interval & $\begin{array}{c}\text { Prosentase } \\
(\boldsymbol{\%})\end{array}$ \\
\hline $60-69$ & 1 & 4,76 \\
\hline $70-79$ & 7 & 33,33 \\
\hline $80-89$ & 11 & 52,38 \\
\hline $90-99$ & 2 & 9,52 \\
\hline Jumlah & 21 & 100 \\
\hline
\end{tabular}




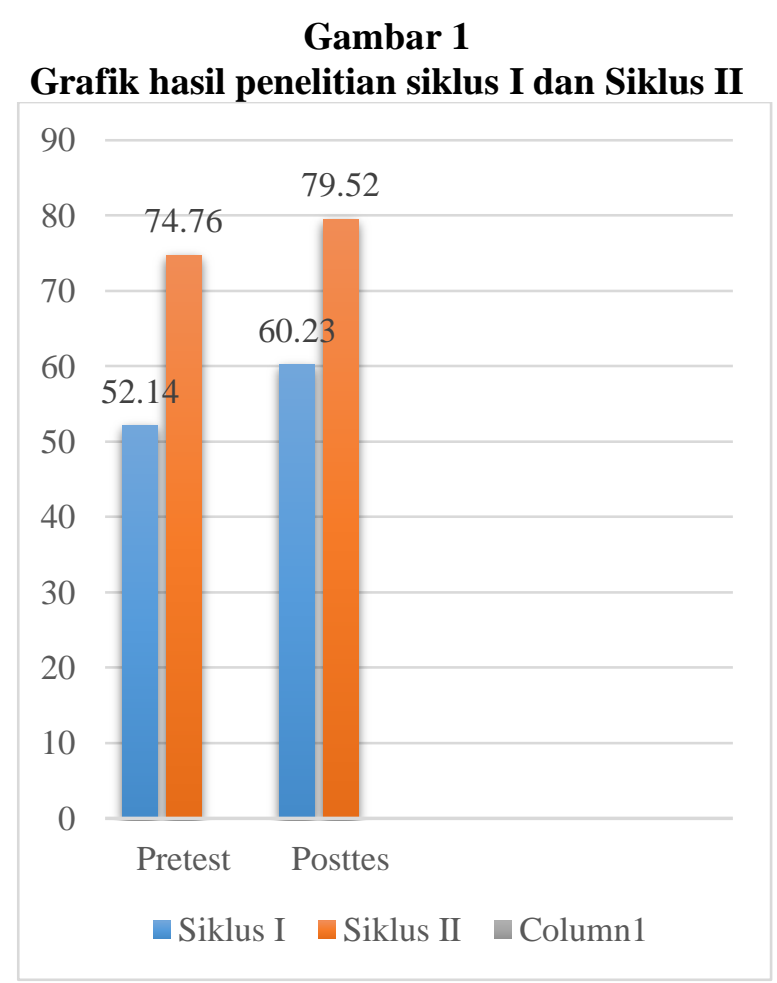

\section{PENUTUP}

\section{Simpulan}

Berdasarkan hasil penlitian dengan judul "Media Film Situs Astana Gede Kawali Untuk Meningkatkan Hasil Belajar Sejarah Siswa" dapat diambil kesimpulan bahwa perencanaan pembelajaran sejarah terdiri dari perencanaan, pelaksanaan, pengamatan, dan refleksi. Kemudian pelaksanaan pembelajaran sejarah menggunakan media film situs Astana Gede Kawali dapat meningkatkan hasil belajar sejarah siswa yang dapat dilihat dari hasil pelaksanaan pembelajaran mulai siklus I dan siklus II, yaitu siklus I hasil pre test belajar siswa, yaitu memperoleh rata-rata 52,14, sedangkan untuk hasil post test siswa memperoleh rata-rata 74,76. Selanjutnya siklus II hasil pre test memperoleh rata-rata 60,23, kemudian hasil post test memperoleh rata-rata 79,52.

\section{Saran}

Berdasarkan hasil penelitian dapat dikemukakan beberapa saran sebagai berikut:

1. Guru Mata Pelajaran Sejarah Guru sebaiknya selalu memperhatikan media pembelajaran yang digunakan, yaitu media yang lebih banyak memberikan informasi kepada siswa tentang sejarah lokal yang dekat dengan lingkungan siswa serta menuntut siswa untuk aktif, sedangkan guru hanya sebagai fasilitator dan motivator. Salah satu media pembelajaran yang dapat digunakan adalah media film situs Astana Gede Kawali.

2. Siswa hendaknya mengenal sejarah lokal yang dekat dengan lingkungannya, serta memahami arti penting dari sejarah tersebut.

3. Peneliti Berikutnya 1) Dengan melihat film sejarah lokal situs Astana Gede Kawali dapat meningkatkan hasil belajar sejarah siswa, maka penggunaan media dapat digabung dengan penggunaan model yang sesuai. 2) Hendaknya penelitian ini dapat digunakan sebagai acuan penelitian selanjutnya, dengan mengkaitkan aspek-aspek yang belum diungkapkan dan dikembangkan.

\section{DAFTAR PUSTAKA}

Darmawan, Wawan. Tt. Sejarah Lokal: (Pengertian, Konten, Dan Pengajaran). file:///C:/Users/ASUS/Downloads/SEJAR AH\%20LOKAL\%20PA\%20WAWAN.pdf

http://www.disparbud.jabarprov.go.id/wisata/de st-det.php?id=1042\&lang=id (Diakses tanggal 24 Januari 2019)

Kusmayadi, Yadi dan Suryana, Aan. 2019. Pengaruh Model Pembelajaran Kooperatif STAD Berbantuan Media Film Situs Astana Gede Kawali Terhadap Kesadaran Sejarah Siswa (Studi Penelitian Kuasi Eksperimen di Kelas X SMAN 1 Baregbeg). Jurnal Agastya Vol. 9 No. 1 Januari 2019.

Kusnoto, Yuver dan Minandar, Fandri. 2017. Pembelajaran Sejarah Lokal: Pemahaman Kontens Bagi Mahasiswa. SOSIAL HORIZON: Jurnal Pendidikan Sosial Vol. 4, No. 1, Juni 2017. ISSN 2407-5299.

Rahdiyanta, Dwi. 2012. Penelitian Tindakan Kelas (Pengertian, Prinsip, dan Karakteristik PTK). Makalah disampaikan pada Seminar Penelitian Tindakan Kelas Bagi Guru SMK yang diselenggarakan oleh Fakultas Teknik Universitas Negeri Yogyakarta pada tanggal 12 Juli 2012.

Septiani, Ayu. Tt. Situs Astana Gede Kawali Sebagai Sumber Belajar Bagi Mahasiswa Sejarah (Studi Kasus pada Mahasiswa Program Studi Sejarah Universitas Padjadjaran). Jurnal Pendidikan dan Sejarah: Candrasangkala ISSN: 24772771, e-ISSN: 2477-8214. 
Sjukur, Sulihin B. 2012. Pengaruh Blended Learning Terhadap Motivasi Belajar Dan Hasil Belajar Siswa Tingkat SMK. Jurnal Pendidikan Vokasi, Vol 2, Nomor 3, November 2012.

Soedarmo, Runalan. (2011). Pelestarian Benda Cagar Budaya dan Upaya Pengembangan Nilai Budaya Situs Astana Gede Sebagai Warisan Peninggalan Sejarah di Kecamatan Kawali Kabupaten Ciamis.Cakrawala Galuh Vol. I No. 6 September 2011.

Suhendri, Huri. 2012. Pengaruh Kecerdasan Matematis-Logis Dan Kemandirian Belajar Terhadap Hasil Belajar Matematika. Jurnal Formatif 1(1): 29-39 ISSN: 2088-351X.

Supardi. 2006. Pendidikan Sejarah Lokal Dalam Konteks Multikulturalisme. Cakrawala Pendidikan, Februari 2006, Th. XXV, No. 1. 